\title{
Overview of Indonesian Law in the Purchase Transaction of Home Ownership Credit (KPR)
}

\author{
Chairuni Nasution
}

Lecture Program Study Law, Faculty of Social Science, Universitas Pembangunan Panca Budi Medan

\begin{abstract}
Home is a basic need that is very important for everyone. However, some people still do not own their own homes. The contributing factor is the high cash price of the house. Therefore, the government through the minister of public housing created a Home Ownership Credit (KPR) program. This KPR program is aimed at low-income people, which is called subsidized KPR. the number of banks implementing the KPR purchase program. This thesis research concerns the KPR transaction system carried out by BTN Syariah North Sumatra and a review of Islamic law on the KPR transaction system at BTN Syariah North Sumatra. This type of research uses normative legal research with a conceptual approach to understanding the KPR BTN Syariah transaction system that uses Islamic principles. The results and discussion of this research are the KPR transaction system carried out by BTN Syariah using the murabahah and istishna sale and purchase contracts. A legal review in Indonesia of this sale and purchase agreement is with 3 approaches consisting of the review of the terms of sale and purchase, the legal terms of sale and purchase, and the terms of buying and selling credit. For the Istishna contract, BTN Syariah cannot use this contract because BTN Syariah is not a producer but a trader. In conclusion, the KPR transaction scheme carried out by BTN Syariah is not essentially a sale and purchase of murabahah or istishna, but of accounts payable / qardh.
\end{abstract}

Keywords: Indonesian law, mortgage, legal relief

\section{INTRODUCTION}

Home is everyone's basic need apart from food and clothing. The house has a very important function for human life. However, many people still do not own their own homes, especially people on low incomes. Low-income people find it very difficult to own a house for cash. This is due to the high price of houses. The right to live in every person has been guaranteed in the 1945 Constitution (hereinafter referred to as the 1945 Constitution) Article $28 \mathrm{H}$ paragraph (1). In the 1945 Constitution, it is explained that "everyone has the right to live in physical and spiritual prosperity, to have a place to live and to have a good and healthy living environment and the right to obtain health services" (Galih Prasetyo \& Muis, 2015).

Long before the 1945 Constitution was amended, namely in 1974, the government through the Letter of the Minister of Finance of the Republic of Indonesia No. B-49 / MK / I / 1974 established a subsidized housing loan program or also known as Home Ownership Credit (hereinafter referred to as KPR). KPR was first realized by a state-owned bank, namely the State Savings Bank, and was implemented in the city of Medan (Eddy et al., 2018).

When the Indonesian Ulama Council argued that the law on bank interest was haram, as stated in the Decree of the Fatwa of the Indonesian Ulema Council Number 1 of 2004 concerning Interest (Fa'idah), conventional banks began to open special branches serving the sharia system. This is based on the fact that people do not want to use bank services that apply an interesting system (Lembaga et al., 2017). The existence of Islamic banking is a must to 
overcome people who want the Islamic concept in every transaction that is free of interest. Therefore, the fundamental difference between Islamic banking and conventional banking is the presence or absence of interest. In Islamic banking, the profit-sharing system is used. "Customers who save at a Sharia bank will not be given interest benefits but profit in the form of profit-sharing" (Akhmad Syarifudin, 2014).

Over time, the Indonesian people who are predominantly Muslim have found that the KPR system carried out by Islamic banking is not by Islamic principles. The name of the contract (transaction) in Islam is used by Sharia banking to run products in Islamic banking. However, the transaction system is not much different from the system practiced by conventional banking. "From this reality, we only want to emphasize one conclusion, that consumers (customers) do not buy and sell houses at all with the bank. Likewise, banks do not buy houses from developers at all. This practice applies to both conventional and Islamic bank (Suberi, 2017). ".

About mortgages carried out by Islamic banking, Islam does not prohibit buying and selling using the credit system. However, if the transactions that have been carried out have violated Islamic law, then that is what is prohibited. One of the transactions that violate Islamic law is a transaction that contains an element of usury. Buying and selling with a credit system is very vulnerable to contain elements of usury. Riba occurs when the debtor is due in payment which is then subject to a fine, then the fine is usury or interest occurs. (Cosco et al., 2010)

\section{LITERATUR REVIEW}

\subsection{Overview of Home Ownership Loans (KPR).}

$\begin{array}{ccc}\text { Buying a house } & \text { or for other } \\ \text { consumptive } & \text { needs } & \text { with a }\end{array}$
guarantee/collateral in the form of a house. Although they are similar in use, KPR is different from construction and renovation loans.11 Home Ownership Credit is a credit facility provided by banks to individual customers who are going to buy or repair houses.

In Indonesia, there are currently 2 types of KPR known:

1) Subsidized KPR, which is a credit allocated to people with middle to lower-income to meet the needs of housing or repairs to existing homes. This subsidized credit regulated separately by the government, so that not every community applying for credit can be granted this facility (Putri et al., 2018).

2) Non-Subsidized KPR, which is a KPR intended for the entire community. The provisions for KPR are determined by the bank so that the determination of the amount of credit and the interest rate is carried out by the policy of the bank concerned(Wibowo et al., 2017).

\subsection{Definition of Buy and Sell House.}

The definition of buying and selling is the process of exchanging assets, or a lawful benefit/service to be exchanged for something similar to it for an unlimited period, in ways that are justified (Mukharom et al., 2020).

What is meant by the definition of assets in the definition of buying and selling above: "Any object whose benefit is lawful even without any need or emergency conditions. Thus it can be understood that any useless object, such as insects, or its use is prohibited, such as musical instruments, pigs, khamar, is not categorized as property. Even in the Shariah, these objects are obliged to be destroyed, as a form of the obligation to deny evil.

In essence, the pillar of sale and purchase is something that must exist in buying and selling, so that transactions can occur. There are 3 pillars of buying and selling, namely:

1) Al-Aqidan: two parties who make the contract or also known as the subject of buying and selling. The subject of buying and selling consists of sellers and buyers. In connection with the parties, the perpetrators 
must have competence in carrying out trading activities, namely those who are pubescent and can vote. Small children who are not yet mumayyiz, crazy people, or people who are forced to do illegitimate transactions.

2) Al-Maq'ud 'Alaih: a contract tool or also known as the object of sale and purchase. The object of sale and purchase of its goods or services.

3) Shighat akad: words or gestures from sellers and buyers that show their desire to do so without coercion.

\subsection{Legitimate Terms of Sale and Purchase Agreement}

There are 7 (seven) distribution of the valid terms of the sale and purchase contract, namely: the first condition, mutual approval is made between the seller and the buyer. The second condition is that the seller and the buyer are among those who are allowed to make transactions (Jaiz atTasharruf). The third requirement, the person who is in the contract must be the owner or represent the owner. A person may not transact other people's property, either selling other people's things or buying with other people's money. The fourth condition, the goods sold, the benefits are permissible and lawful. The fifth requirement, items that are possible to be handed over. Goods that are traded can be handed over to those who are entitled to receive them. Selling nontransferable items include gambling. The sixth requirement, the goods must be known when the contract. The seventh condition, the price of the goods has been determined when the contract. The price of the goods being traded must be clear when the contract is in progress so that it is not justified for them to separate before the price of the goods has been agreed upon (Agreement, 1997).

\section{METHOD OF RESEARCH}

This research is normative legal research, namely research that places the law as a norm system building. The system of norms in question is regarding the principles, norms, rules of legislation, court decisions, agreements, and doctrines (teachings). This study uses a conceptual approach to understand the Sharia Banking KPR transaction system.

This study also seeks the concept of a KPR transaction system into a Sharia State Savings Bank that uses Islamic principles. literature study to provide a legal opinion in the form of justification (prescriptive) of a legal event. Legal materials as research materials are taken from literature in the form of primary legal materials, secondary legal materials, tertiary legal materials, and non-legal materials. To obtain legal materials, both primary, secondary, and tertiary, as well as non-legal materials in this study will be taken in: local libraries, Sharia State Savings Bank in the city of Medan, and printed mass media and internet media.

This data analysis method is very necessary for solving the problems that have been raised above. The collected data will be analyzed prescriptively in an inductive way, namely specific data about the KPR transaction system at the Medan Sharia Savings Bank to be systematically arranged to produce arguments for the KPR transaction system at the Medan Sharia Savings Bank which is by Islamic principles and by legislation. -the correct invitations.

\section{ANALYZE AND RESULT}

There are 2 contracts in the KPR transaction system at BTN Syariah, namely the murabahah contract in the KPR Platinum iB product and the KPR Sejahtera and the istishna contract in the Indesya $\mathrm{iB}$ KPR product. There are 3 stages of the contract in housing murabahah financing for BTN Syariah, namely the wakalah contract, which is a supporting contract that functions to give customers the right to represent the bank in buying a house to the developer. The first murabahah contract is that the house in principle belongs to the bank (the bank buys to the developer) and can be sold to the customer, which is then followed by the second murabahah contract as an 
agreement to sell the house in installments to the customer.

There are several approaches that the author will use to review the contract. The first, in terms of the pillars of buying and selling. In that research conducted by Reginald in his thesis entitled "Analysis of Murabahah Housing Financing Agreement (KPR Syariah) at BTN Syariah According to Islamic Bond Law" the bank makes buying and selling to developers on behalf of customers. However, this cannot be justified, even though the author got his data from an interview with one of the bank employees. There are several reasons why this cannot be justified. The first is that the bank should serve customers fully, not customers who are asked to become bank representatives in transactions to developers.

The second point is that the customer makes a sale and purchase with the developer without the customer as a representative, but the customer does it for himself and the customer enters into a debt agreement with the bank. If the customer is the representative, the customer may not pay the down payment to the developer. Then, if the customer is the representative of the bank, the customer is not justified in making a price deal from bargaining without an order from the bank as the representative. If the essence of the KPR transaction system carried out by BTN Syariah is a financing contract, not a sale and purchase agreement, then BTN Syariah may not take a margin or profit in the financing contract. The scholars have agreed that all debts for which there is a gain or benefit have the status of usury.

Second, in terms of the legal terms of sale and purchase. One of the legal requirements for buying and selling is that the goods sold are not owned by other people. From the transaction scheme described above, there will be irregularities in the status of the house, does it belong to the bank which is then sold to the customer? In the wakalah agreement letter between the customer and the bank, there is a clause that the customer with this contract hands over the house and related documents to the bank, and the bank in principle accepts the house along with the documents referred to. However, this clause is very strange, the reason is that in Article 3 concerning the provisions for banks. There it is stated that the first bank gives the right to the customer to sign the sale and purchase deed for and on behalf of the customer with the developer/seller and the second bank will make a payment for the purchase price of the house to the developer/seller after the customer signs the KPR BTN Platinum iB financing contract.

The real essence of the KPR system at BTN Syariah is by the wakalah agreement, what is approaching is that the bank has sold goods that are not yet its legal property. Combining the wakalah contract with the murabahah contract is permissible, but all the pillars and conditions of wakalah and murabahah are fulfilled. But in general, Islamic banks will not want to comply because it will require them to bear the risks that are usually borne by trading companies in general, such as the possibility of order cancellation by customers. In other words, Islamic banks are not mentally ready to buy and sell goods because they are used to buying and selling money.

According to the jumhur of scholars, the istishna contract is a special type of salam contract so that the conditions are the same as the terms of the salam contract. All prices of goods and time of delivery of goods must be clear by the order.26 In an istishna contract, the seller is the producer and there is an advance payment or DP. While the salam contract is carried out by the trader, the down payment must not be made in cash, even though the goods are delivered for several days.

\section{CONCLUSION}

From the discussion that has been described in the discussion above, it can be taken the following conclusions:

1. The KPR transaction system carried out by BTN Syariah is to use a contract murabahah in KPR Platinum $\mathrm{iB}$ and KPR 
Sejahtera products and istishna contracts in KPR Indesya iB products. The murabahah contract uses 3 stages of the contract, namely the first wakalah contract where the bank gives the customer the right to represent the bank to buy a house from the developer, the second is the first murabahah contract where the bank buys the house from the developer in cash, the third is the second murabahah contract where the bank sells the house to customers on credit. Meanwhile, the istishna contract uses the scheme of customers ordering a house from a bank where the condition of the house has not been built or is still under construction and is under construction, the customer is not required to pay in installments.

The stages in the istishna contract are:

a. The customer orders a house from the bank where the condition of the house is not yet finished.

b. Banks order and buy from developers.

c. The bank sells to customers.

2. Review of Islamic Law on the KPR Transaction System at BTN Syariah A. Review of Islamic Law on KPR with Murabahah Agreement

There are 3 approaches taken by the author in reviewing the KPR transaction system at BTN Syariah, namely: The first is in terms of harmony in buying and selling. The KPR system carried out by BTN Syariah with a murabahah contract is a triangular credit system. In essence, the bank is not directly involved in this triangular credit system because the bank is only represented by customers to buy houses from developers. So from that, what's the difference with a transaction where the bank lends money to customers to buy a house. So in this transaction, the developer acts as the seller or the owner of the house, the customer as a buyer or in need of a house, and the bank as a provider of funds for customers who cannot buy in cash. The second is in terms of the legal terms of sale and purchase. One of the legal requirements for buying and selling is that the goods sold do not belong to anyone else. This means that the item already belongs to him and is under his control.

The merger of the wakalah and murabahah contracts in the KPR transaction system raises question marks about the status of the houses that are sold by the bank to customers. The real essence of this KPR transaction system is that the house has not been legally owned by the bank so that the bank has sold items that are not yet its property. Because the developer hands over the house directly to the customer and the house certificate directly in the customer's name. The third is in terms of the terms of sale and purchase credit. In a KPR transaction with a murabahah contract carried out by BTN Syariah, the conditions for buying and selling credit are not fulfilled. One of them is still there clause of late fines if the customer is late in paying installments and the bank has camouflaged usury, where the bank in front of the customer declares a sale and purchase but in front of the Director-General of Taxes declares financing so that the bank avoids the name double tax.

The istishna contract which is a KPR product at BTN Syariah is very strange because the bank is not a producer. The proof is in the istishna contract scheme the bank has to order and buy from the developer, while the developer becomes the producer.

This means that what makes a house is not a bank but a developer. This is the position the bank is only a trader so that the bank is not allowed to carry out the contract istishna. Traders are only allowed to use the salam contract in selling transactions buy orders.

Acknowledgement: None

Conflict of Interest: None

Source of Funding: None 


\section{REFERENCES}

1. Agreement, C. (1997). Copyright agreement. Academic Radiology, 4(2), 9A. https://doi.org/10.1016/S10766332(97)80022-0

2. Akhmad Syarifudin. (2014). Pengaruh Kompetensi SDM dan Peran Audit Intern terhadap Kualitas Laporan Keuangan Pemerintah Daerah dengan Variabel Intervening Sistem Pengendalian Internal Pemerintah (studi empiris pada Pemkab Kebumen) Akhmad Syarifudin. Jurnal Fokus Bisnis, Volume 14, No 02, Desember 2014, 14(25), 26-44.

3. Cosco, N. G., Moore, R. C., \& Islam, M. Z. (2010). Behavior mapping: a method for linking preschool physical activity and outdoor design. Medicine \& Science in Sports \& Exercise, 42(3), 513-519.

4. Eddy, T., Alamsyah, B., Fatmawati, I., Aryza, S., Putera, A., \& Siahaan, U. (2018). Enhancement operation system model in managing local resources-based environment towards sustainable development. International Journal of Civil Engineering and Technology, 9(10).

5. Galih Prasetyo, A., \& Muis, A. (2015). Pengelolaan Keuangan Desa Pasca UU No. 6 Tahun 2014 Tentang Desa: Potensi Permasalahan dan Solusi. Jurnal Desentralisasi, 13(1), 16-31.

6. Lembaga, D. I., Studi, P., Di, K., Cipinang, P., Hukum, P., \& Hukum, B. (2017). Sistem hukum pencegahan peredaran narkotika di lembaga pemasyarakatan (studi kasus di lembaga pemasyarakatan cipinang). 6(April), 111-123.

7. Mukharom, Indah Astanti, D., \& Tuti Muryati, D. (2020). Analisis Normatif Terhadap Putusan Praperadilan No. 04/PID.PRAP/2015/PN. Berdasarkan Prespektif Kemanfaatan, Kepastian Hukum dan Keadilan. Diktum: Jurnal Ilmu Hukum, 8(1), 1-35. https://doi.org/10.24905/diktum.v8i1.89

8. Putri, M., Wibowo, P., Aryza, S., Utama Siahaan, A. P., \& Rusiadi. (2018). An implementation of a filter design passive lc in reduce a current harmonisa. International Journal of Civil Engineering and Technology, 9(7).

9. Suberi, M. (2017). The International Journal Of Business \& Management New Method Practice Business Process Outsourcing and Manpower Outsourcing the Banking Sector in Indonesia. 5(3), 132-136.

10. Wibowo, P., Lubis, S. A., Hermansyah, ., Hamdani \& Tharo, Z. (2017). Smart Home Security System Design Sensor Based on Pir and Microcontroller. International Journal of Global Sustainability, 1(1), 67. https://doi.org/10.5296/ijgs.v1i1.12053

How to cite this article: Nasution C. Overview of Indonesian law in the purchase transaction of home ownership credit (KPR). International Journal of Research and Review. 2021; 8(5): 286-291. DOI: https://doi.org/10.52403/ijrr. 20210536 